\title{
Effect of Plant Height on Fusarium Head Blight in Spring Wheat
}

\author{
Hana Moidu ${ }^{1}$, Jane Brownlee ${ }^{1}$, Xuelain Wang ${ }^{1}$, Ian Deschiffart ${ }^{1}$, Linda Langille ${ }^{1}$, Harvey Voldeng ${ }^{1} \&$ \\ Shahrokh Khanizadeh ${ }^{1}$ \\ ${ }^{1}$ Eastern Cereals and Oilseed Research Centre, Agriculture and Agri-Food Canada, Ottawa, Ontario, Canada \\ Correspondence: Shahrokh Khanizadeh, Eastern Cereals and Oilseed Research Centre, Agriculture and \\ Agri-Food Canada, K.W. Neatby Building, Ottawa, Ontario, Canada, K1A 0C6. Tel: 1-613-759-6563, E-mail: \\ Shahrokh.Khanizadeh@agr.gc.ca; http://khanizadeh.info
}

Received: April 21, 2014 Accepted: June 4, 2015 Online Published: August 13, 2015

doi:10.5539/jps.v4n2p105 URL: http://dx.doi.org/10.5539/jps.v4n2p105

\begin{abstract}
Fusarium Head Blight (FHB), caused by the fungal species Fusarium graminearum, is a disease affecting wheat cultivars across Canada. Recent and severe outbreaks have spurred research in developing FHB-resistant cultivars and evaluating the underlying causes of FHB susceptibility. In this study, the effect of plant height on Fusarium Head Blight in Canadian spring wheat was evaluated over a two-year period. Cultivars of spring wheat varying in origin, height, and disease susceptibility were artificially inoculated with FHB, and the subsequent disease symptoms and height data was collected. It was found that plant height is negatively correlated with FHB incidence and severity. However, varieties originating from Eastern Canada had a much stronger negative correlation between plant height and FHB, whereas the trials with Western Canada origins had a weaker correlation.
\end{abstract}

Keywords: Fusarium Head Blight, spring wheat, plant height, Canada, correlation

\section{Introduction}

Fusarium Head Blight (FHB), caused by the fungal species Fusarium graminearum, is the principal head blight pathogen in Canada and around the world (Sutton, 1982). This fungus is prevalent in areas of high precipitation, high humidity, or heavy dews (Windels, 2000) and commonly attacks wheat spikes and stems at the heading stage (Sutton, 1982). Plants infected with FHB are characterized by: dark purple, brown, or black lesions on the glume and florets, deformed awns (Yuen \& Schoneweis, 2007), premature blighting, bleaching of spikes, sterile florets and poorly filled grains (Sutton, 1982). In recent years, severe FHB outbreaks have occurred in Canada, specifically in the provinces of Ontario, Quebec, the Maritimes, Manitoba and Alberta (Sutton, 1982).

The susceptibility of wheat lines to FHB is of great concern to the agri-food industry (Miller et al., 2010), because plants infected with this disease have lower yields, shriveled and discolored kernels, and lighter-weight and poorer-quality seeds (Windels, 2000). Furthermore, F. graminearum produces the mycotoxin deoxynivalenol, commonly referred to as DON, on the infected grain, which then becomes unsuitable for flour, cereals, or malt and too toxic for use as non-ruminant animal feed (Windels, 2000). These symptoms are the cause of wheat losses of nearly $\$ 300$ million over a five year period in certain provinces (Windels, 2000). Because of the prevalence, severity, and detrimental commercial implications of FHB, the USDA ranks it as the worst plant disease since the 1950s. The damaging effect of F. graminearum on wheat plants has led to a demand for resistant varieties and spurred much research on the subject. Plant resistance mechanisms for FHB can be active or passive; examples include physiological processes for active mechanisms and morphological features for passive mechanisms (Mesterházy, 2006). Scientists have evaluated many factors that influence passive resistance, such as awn presence and floret density on spikes (Yuen \& Schoneweis, 2007), however plant height in Canadian trials has not yet been evaluated in any depth. The purpose of this study was to examine the relationship between plant height and FHB incidence and its severity for Eastern and Western Canadian spring wheat varieties. 


\section{Materials and Methods}

\subsection{Field Preparation and Plant Materials}

This study was conducted over a two-year period, in 2013 and 2014, at the Eastern Cereal and Oilseed Research Centre located in Ottawa, Ontario, Canada. The Fusarium nursery was planted in a different field each year, however both fields had been planted with corn in the previous year, and both fields had a sand-sandy loam soil type. Field preparation was consistent in both years: individual plots of spring wheat varieties varying in FHB susceptibility, plant height, and origin were planted in two parallel rows, each $1.0 \mathrm{~m}$ long and $0.1 \mathrm{~m}$ wide. Herbicides were applied two weeks after emergence: in 2013, Buctril M at $1.0 \mathrm{~L} \mathrm{ha}^{-1}$ and Puma at $770 \mathrm{~mL} \mathrm{ha}^{-1}$ were applied, and in 2014, Buctril M at $1.0 \mathrm{~L} \mathrm{ha}^{-1}$ and Puma at $1.02 \mathrm{~L} \mathrm{ha}^{-1}$ were applied. In each year, the field was sprinkler-irrigated twice daily and hand-weeded periodically.

\subsection{Inoculum Preparation and Application and Fusarium Head Blight Assessment}

The Fusarium inoculum was prepared using a 1:1 barley and corn mixture, which was soaked for 24 hours and autoclaved at $120{ }^{\circ} \mathrm{C}$ twice for 90 minutes each time. The autoclaved grain was seeded with $80 \mathrm{~mL}$ of three separate FHB strains (DAOM 178148, DAOM 212678, and DAOM 232369) and stored in covered trays for four to six weeks. After the wheat was planted and 15 days before heading occurred, fresh inoculum was hand-applied twice between the planted rows at a rate of $50 \mathrm{~g} \mathrm{~m}^{-2}$, immediately after which the field was irrigated.

Percent severity and percent incidence of FHB disease were determined 24 days after $50 \%$ of the plant heads in the plot showed extended anthesis. Fusarium Head Blight occurrence on the plant head is measured by obtaining the product of the percent severity and percent incidence values and is called the FHB index. Height measurements were taken in centimeters by placing a standard measuring stick in a single row and recording the average plant height for the plot. Lodging, awn presence, and plot abnormalities were also collected.

\subsection{Statistical Analysis}

Analysis of variance was performed on the data sets using Stata 13 software. Pearson's correlation coefficients, probability values, means, and range values were determined.

\section{Results}

The results from the 2013 and 2014 replications of this study are consistent. In 2013 (Table 1), the trials originating from Western Canada did not support the hypothesis that plant height is correlated with FHB index. Given the critical value $\mathrm{P}=0.01$, only 5 of the 18 Western trials showed statistical significance between plant height and FHB index. Conversely, 9 of the 15 Eastern trials showed statistical significance between plant height and FHB index. The Western trials also had, on average, a much lower Pearson's correlation coefficient than the Eastern trials did $(-0.21$ vs. -0.51$)$.

The results from the 2014 replication parallel those from 2013 (Table 2). Of the 14 Western trials, only 8 showed statistical significance between plant height and FHB index, whereas of the 28 Eastern trials, 26 showed statistical significance between plant height and FHB index. The Western trials also had, on average, a much lower Pearson's correlation coefficient than the Eastern trials did ( -0.011 vs. -0.220$)$.

In both the 2013 and 2014 replications of this study, the Eastern plant height mean is approximately $10 \mathrm{~cm}$ greater than the Western plant height mean. This difference in plant height is matched by a $2 \%$ to $3 \%$ difference in FHB index between the Eastern and Western trials. However, after a $t$ test for FHB, means between the Eastern and Western trials was performed, P values of 0.6913 for the 2013 data and 0.3842 for the 2014 data were obtained. From this we can conclude that the $2 \%$ to $3 \%$ difference in FHB index between the Eastern and Western trials is not statistically significant.

To summarize, the Eastern trials showed strong statistical significance between plant height and FHB index in both 2013 and 2014, whereas the Western trials did not. Although the Western trials had both consistently shorter plants and a higher FHB index than the Eastern trials did, this difference in FHB index was not significant and can therefore not be explained by the difference in plant height. The average Pearson's correlation coefficients for the Eastern and Western trials were consistent with the general trend: there is a strong correlation with the Eastern trials whereas the Western trials show a weaker correlation. 
Table 1. Pearson's correlation coefficient (r) between wheat plant height and Fusarium head blight (FHB) resistance scores in 33 trials at the Eastern Cereal and Oilseed Research Centre in 2013 using genetic materials received from several breeding programs in Eastern and Western Canada

\begin{tabular}{|c|c|c|c|c|c|c|c|c|}
\hline \multirow[b]{2}{*}{ Trial } & \multirow[b]{2}{*}{ Origin } & \multirow[b]{2}{*}{$\mathrm{r}$} & \multirow[b]{2}{*}{ Probability } & \multirow[b]{2}{*}{$\mathrm{n}$} & \multicolumn{2}{|c|}{ FHB (\%) } & \multicolumn{2}{|c|}{ Height $(\mathrm{cm})$} \\
\hline & & & & & Mean & Range & Mean & Range \\
\hline 1 & Eastern & -0.49 & 0.034 & 36 & 37.1 & 33.1 & 100 & 76 \\
\hline 2 & Eastern & -0.69 & 0.000 & 36 & 31.5 & 94.9 & 91 & 25 \\
\hline 3 & Eastern & -0.48 & 0.002 & 42 & 26 & 91.9 & 91 & 28 \\
\hline 4 & Eastern & -0.5 & 0.000 & 60 & 38 & 91.7 & 93 & 37 \\
\hline 5 & Eastern & -0.48 & 0.014 & 27 & 55.7 & 82.4 & 80 & 27 \\
\hline 6 & Eastern & -0.42 & 0.081 & 20 & 21.6 & 91.7 & 87 & 23 \\
\hline 7 & Eastern & -0.7 & 0.000 & 32 & 36.5 & 90.1 & 100 & 44 \\
\hline 8 & Eastern & -0.49 & 0.005 & 33 & 41.8 & 88.5 & 83 & 37 \\
\hline 9 & Eastern & -0.68 & 0.000 & 56 & 45.7 & 76.8 & 82 & 35 \\
\hline 10 & Eastern & -0.64 & 0.000 & 32 & 36.5 & 85 & 98 & 36 \\
\hline 11 & Eastern & -0.13 & 0.500 & 32 & 30.5 & 91.3 & 100 & 37 \\
\hline 12 & Eastern & -0.5 & 0.005 & 32 & 36.1 & 89.1 & 101 & 37 \\
\hline 13 & Eastern & -0.77 & 0.000 & 32 & 43.3 & 63 & 101 & 38 \\
\hline 14 & Eastern & -0.38 & 0.102 & 22 & 36.4 & 81.9 & 86 & 26 \\
\hline 15 & Eastern & -0.34 & 0.663 & 6 & 42.5 & 14.9 & 96 & 27 \\
\hline 16 & Western & -0.55 & 0.000 & 60 & 25.1 & 90.4 & 95 & 35 \\
\hline 17 & Western & -0.37 & 0.004 & 90 & 27.8 & 85.9 & 84 & 23 \\
\hline 18 & Western & -0.43 & 0.000 & 90 & 23 & 82.2 & 85 & 28 \\
\hline 19 & Western & -0.71 & 0.000 & 35 & 25.4 & 94.6 & 85 & 28 \\
\hline 20 & Western & -0.06 & 0.654 & 56 & 29.4 & 73.5 & 80 & 30 \\
\hline 21 & Western & -0.08 & 0.563 & 56 & 39.3 & 63.9 & 85 & 27 \\
\hline 22 & Western & 0.03 & 0.878 & 36 & 43 & 60 & 83 & 23 \\
\hline 23 & Western & -0.28 & 0.150 & 30 & 27.5 & 25.5 & 88 & 19 \\
\hline 24 & Western & -0.22 & 0.268 & 30 & 70.7 & 45 & 78 & 16 \\
\hline 25 & Western & -0.52 & 0.004 & 32 & 46 & 85.4 & 82 & 23 \\
\hline 26 & Western & -0.3 & 0.126 & 30 & 31.2 & 59.4 & 81 & 23 \\
\hline 27 & Western & 0.27 & 0.159 & 30 & 29.6 & 55.9 & 91 & 20 \\
\hline 28 & Western & 0.11 & 0.446 & 56 & 59.4 & 54.3 & 81 & 26 \\
\hline 29 & Western & -08 & 0.564 & 56 & 54.2 & 60.2 & 77 & 29 \\
\hline 30 & Western & -0.11 & 0.438 & 56 & 37.2 & 52.5 & 77 & 21 \\
\hline 31 & Western & 0.13 & 0.352 & 56 & 37 & 67.5 & 81 & 23 \\
\hline 32 & Western & -09 & 0.641 & 32 & 41.1 & 80 & 81 & 27 \\
\hline \multirow[t]{3}{*}{33} & Western & -0.5 & 0.011 & 27 & 52.8 & 92.6 & 86 & 31 \\
\hline & Eastern & -0.51 & 0.094 & 33.2 & 37.3 & 77.8 & 92 & 35 \\
\hline & Western & -0.21 & 0.292 & 47.7 & 38.9 & 68.3 & 83 & 25 \\
\hline
\end{tabular}

Origin was defined by the origin of the varieties tested. Probability was defined by the probability, under the assumption of hypothesis $\mathrm{H}$, of obtaining a result equal to or more extreme than what was actually observed. $\mathrm{n}$ was defined by the number of varieties tested. FHB (\%) was defined by Fusarium Head Blight index in percent, obtained from the product of FHB severity in percent and FHB incidence in percent. Height $(\mathrm{cm})$ was defined by the average height of a variety. 
Table 2. Pearson's correlation coefficient (r) between wheat plant height and Fusarium head blight (FHB) resistance scores in 42 trials at the Eastern Cereal and Oilseed Research Centre in 2014 using genetic materials received from several breeding programs in Eastern and Western Canada

\begin{tabular}{|c|c|c|c|c|c|c|c|c|}
\hline \multirow[b]{2}{*}{ Trial } & \multirow[b]{2}{*}{ Origin } & \multirow[b]{2}{*}{$\mathrm{r}$} & \multirow[b]{2}{*}{ Probability } & \multirow[b]{2}{*}{$\mathrm{n}$} & \multicolumn{2}{|c|}{ FHB (\%) } & \multicolumn{2}{|c|}{ Height $(\mathrm{cm})$} \\
\hline & & & & & Mean & Range & Mean & Range \\
\hline 1 & Eastern & -0.27 & 0.000 & 270 & 23.0 & 82.5 & 84 & 62 \\
\hline 2 & Eastern & -0.62 & 0.000 & 60 & 24.0 & 57.5 & 89 & 47 \\
\hline 3 & Eastern & -0.38 & 0.000 & 216 & 22.7 & 97.0 & 89 & 42 \\
\hline 4 & Eastern & -0.26 & 0.000 & 216 & 25.2 & 97.0 & 90 & 61 \\
\hline 5 & Eastern & -0.22 & 0.001 & 216 & 23.9 & 42.0 & 96 & 48 \\
\hline 6 & Eastern & -0.55 & 0.000 & 108 & 33.4 & 92.0 & 95 & 72 \\
\hline 7 & Eastern & -0.11 & 0.253 & 108 & 29.3 & 96.5 & 95 & 47 \\
\hline 8 & Eastern & -0.41 & 0.000 & 216 & 20.7 & 42.0 & 84 & 58 \\
\hline 9 & Eastern & -0.31 & 0.000 & 216 & 24.8 & 42.0 & 91 & 47 \\
\hline 10 & Eastern & -0.57 & 0.000 & 75 & 24.1 & 37.0 & 95 & 42 \\
\hline 11 & Eastern & -0.20 & 0.008 & 180 & 23.6 & 42.0 & 90 & 34 \\
\hline 12 & Eastern & -0.29 & 0.000 & 180 & 33.6 & 82.0 & 97 & 53 \\
\hline 13 & Eastern & -0.57 & 0.000 & 75 & 50.7 & 77.0 & 84 & 71 \\
\hline 14 & Eastern & -0.56 & 0.000 & 60 & 54.9 & 71.0 & 78 & 51 \\
\hline 15 & Eastern & -0.39 & 0.001 & 75 & 18.7 & 32.0 & 97 & 37 \\
\hline 16 & Eastern & -0.50 & 0.000 & 81 & 39.3 & 91.0 & 108 & 58 \\
\hline 17 & Eastern & -0.73 & 0.000 & 93 & 39.4 & 91.0 & 104 & 56 \\
\hline 18 & Eastern & -0.15 & 0.006 & 360 & 31.7 & 97.5 & 96 & 76 \\
\hline 19 & Eastern & -0.29 & 0.000 & 168 & 38.6 & 92.0 & 96 & 42 \\
\hline 20 & Eastern & -0.59 & 0.000 & 96 & 40.1 & 96.5 & 106 & 60 \\
\hline 21 & Eastern & -0.42 & 0.000 & 96 & 39.5 & 96.5 & 103 & 48 \\
\hline 22 & Eastern & -0.60 & 0.000 & 96 & 45.8 & 96.5 & 101 & 55 \\
\hline 23 & Eastern & -0.65 & 0.000 & 66 & 38.0 & 96.5 & 103 & 62 \\
\hline 24 & Eastern & -0.59 & 0.000 & 42 & 46.7 & 97.5 & 86 & 44 \\
\hline 25 & Eastern & -0.25 & 0.032 & 75 & 47.6 & 77.0 & 112 & 55 \\
\hline 26 & Eastern & -0.58 & 0.000 & 48 & 49.8 & 71.0 & 85 & 50 \\
\hline 27 & Eastern & -0.54 & 0.007 & 24 & 36.5 & 62.0 & 111 & 30 \\
\hline 28 & Eastern & -0.44 & 0.000 & 90 & 36.5 & 97.0 & 97 & 42 \\
\hline 29 & Western & -0.21 & 0.001 & 243 & 25.4 & 50.0 & 86 & 38 \\
\hline 30 & Western & -0.62 & 0.000 & 81 & 32.5 & 97.0 & 90 & 50 \\
\hline 31 & Western & -0.26 & 0.000 & 270 & 24.2 & 62.0 & 83 & 40 \\
\hline 32 & Western & -0.31 & 0.000 & 270 & 27.3 & 67.0 & 85 & 53 \\
\hline 33 & Western & -0.42 & 0.000 & 108 & 33.6 & 72.0 & 87 & 42 \\
\hline 34 & Western & -0.11 & 0.311 & 90 & 52.4 & 75.0 & 96 & 38 \\
\hline 35 & Western & -0.19 & 0.104 & 75 & 32.7 & 51.5 & 89 & 28 \\
\hline 36 & Western & -0.38 & 0.000 & 90 & 48.4 & 65.0 & 84 & 43 \\
\hline 37 & Western & 0.00 & 0.993 & 75 & 40.4 & 60.0 & 90 & 44 \\
\hline 38 & Western & -0.27 & 0.004 & 112 & 56.4 & 55 & 83 & 42 \\
\hline 39 & Western & 0.13 & 0.091 & 180 & 30.7 & 51 & 78 & 38 \\
\hline 40 & Western & 0.03 & 0.683 & 180 & 32.4 & 45 & 78 & 44 \\
\hline 41 & Western & -0.22 & 0.006 & 163 & 47.5 & 75 & 84 & 40 \\
\hline \multirow[t]{3}{*}{42} & Western & -0.01 & 0.892 & 90 & 38.6 & 77 & 87 & 47 \\
\hline & Eastern & -0.43 & 0.011 & 129 & 34.4 & 76.1 & 95 & 52 \\
\hline & Western & -0.20 & 0.220 & 145 & 37.3 & 64.5 & 86 & 42 \\
\hline
\end{tabular}

Origin was defined by the origin of the varieties tested. Probability was defined by the probability, under the assumption of hypothesis $\mathrm{H}$, of obtaining a result equal to or more extreme than what was actually observed. $\mathrm{n}$ was defined by the number of varieties tested. FHB (\%) was defined by Fusarium Head Blight index in percent, obtained from the product of FHB severity in percent and FHB incidence in percent. Height $(\mathrm{cm})$ was defined by the average height of a variety. 


\section{Discussion}

The results of this study confirm the hypothesis of an overall negative linear correlation between plant height and FHB severity and incidence. However, there is a distinct difference between the trials with the Eastern spring wheat varieties and those with the Western spring wheat varieties.

The Eastern trials showed a strong negative relationship between plant height and FHB index, meaning that taller plants were less susceptible to FHB than shorter plants were. One possible explanation for this difference is that in taller plants, the spikes and flowering heads are farther away from the soil surface, which is where $F$. graminearum spores are found. Fusarium Head Blight is more likely to infect plants that are closer to the ground, and thus, taller plants are at an advantage. Another possible explanation is that the microclimate of taller plants is less favorable to the disease: relative humidity is lower at higher spike heights, and because FHB thrives in humid climates, taller plants are less vulnerable to infection.

Conversely, the Western trials did not show dependence between plant height and FHB index. Not only did many of the individual trials not show statistical significance, the correlation was markedly weaker than it was in the Eastern trials. The low Pearson's correlation coefficient for the Western trials signifies that factors other than plant height are causing the incidence and severity of FHB. These auxiliary factors can include morphological traits such as awn presence, floret density on spikes, or anther extrusion. Alternatively, whereas structural features such as plant height largely governed the Eastern trials, genetic differences could have governed the Western trials. Researchers have proposed pleiotropic explanations ( $\mathrm{Lu}$ et al., 2010) for FHB in wheat. If there is a similarity in genetics in the Western varieties, pleiotropy may be the underlying reason for the inconsistency between plant height and FHB correlation in the Western trials.

Regardless of the Western and Eastern origin distinction, plant height was still a dominant factor influencing the incidence and severity of FHB, with a total of $64 \%$ of trials supporting the hypothesis. Although taller plants are significantly less susceptible to FHB, they are also known to be linked to lower yields, reduced fertilizer efficacy, and lodging problems. Further research is required to develop wheat varieties that optimize yield and disease resistance.

\section{References}

Lu, Q., Lillemo, M., Skinnes, H., He, X., Shi, J., Ji, F., .. Bjørnstad, Å. (2013). Anther extrusion and plant height are associated with Type I resistance to Fusarium head blight in bread wheat line 'Shanghai-3/Catbird'. Theoretical and Applied Genetics, 126, 317-334. http://dx.doi.org/10.1007/s00122-012-1981-9

Mesterházy, A. (1995). Types and components of resistance to Fusarium head blight of wheat. Plant Breeding, 114, 377-386. http://dx.doi.org/10.1111/j.1439-0523.1995.tb00816.x

Miller, J. D., Young, J. C., \& Sampson, D. R. (1985). Deoxynivalenol and Fusarium head blight resistance in $\begin{array}{lllll}\text { spring cereals. Journal of } & \text { 359-367. }\end{array}$ http://dx.doi.org/10.1111/j.1439-0434.1985.tb04837.x

Sutton, J. C. (1982). Epidemiology of wheat head blight and maize ear rot caused by Fusarium graminearum. Canadian Journal of Plant Pathology, 4, 195-209. http://dx.doi.org/10.1080/07060668209501326

Windels, C. E. (2000). Economic and social impacts of Fusarium head blight: Changing farms and rural communities in the Northern Great Plains. Phytopathology, 90, 17-21. http://dx.doi.org/10.1094/PHYTO.2000.90.1.17

Yuen, G. Y., \& Schoneweis, S. D. (2007). Strategies for managing Fusarium head blight and deoxynivalenol accumulation in wheat. International Journal of Food Microbiology, 119, 126-130. http://dx.doi.org/10.1016/j.ijfoodmicro.2007.07.033

\section{Copyrights}

Copyright for this article is retained by the author(s), with first publication rights granted to the journal.

This is an open-access article distributed under the terms and conditions of the Creative Commons Attribution license (http://creativecommons.org/licenses/by/3.0/). 